\title{
Marchiafava-Bignami disease
}

\author{
An acquired callosotomy
}

Figure Corpus callosum tractography and MRI findings in Marchiafava-Bignami disease compared to age- and sex-matched control subject

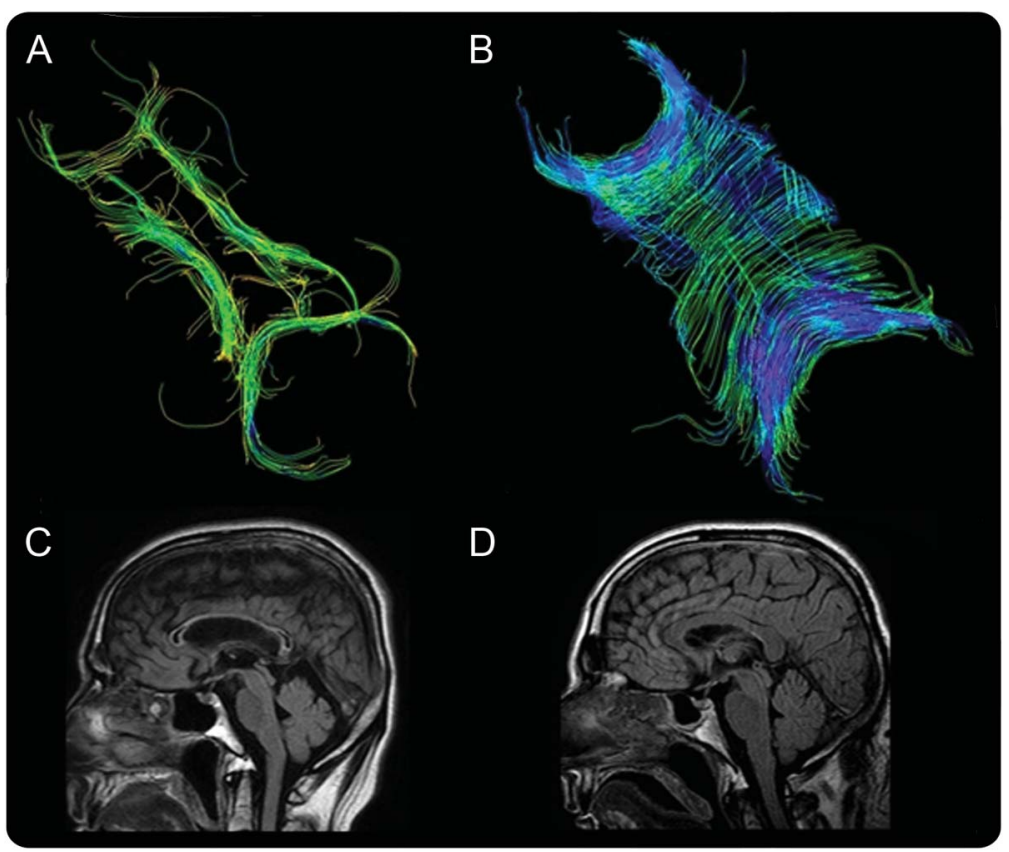

(A) Corpus callosum (CC) tractography in Marchiafava-Bignami disease shows lack of midline transverse fibers. (B) CC tractography of control subject. (C) Sagittal fluid-attenuated inversion recovery (FLAIR) image depicts central CC atrophy (low signal intensity) with sparing of the peripheral layers (hyperintense signal). (D) Sagittal FLAIR image of control subject.

A 57-year-old man with a history of chronic alcoholism was evaluated for seizures. MRI showed severe diffuse atrophy of the corpus callosum (CC). Clinical examination revealed bimanual coordination difficulties, left ideomotor apraxia, and tactile anomia. The genu and the splenium had central cystic degeneration, with sparing of the peripheral layers. Tractography showed the lack of central white matter tracts, an "acquired callosotomy" (figure). The imaging findings were compatible with the chronic phase of Marchiafava-Bignami disease, a rare demyelinating disorder, primarily affecting the central CC layers, thought to be due to chronic alcohol consumption. ${ }^{1,2}$

Andrea Lakatos, MD, Paraskevi Kosta, MD, PhD, Spyridon Konitsiotis, MD, PhD, Anastasia K. Zikou, MD, PhD, Loukas G. Astrakas, PhD, Maria I. Argyropoulou, MD, PhD

From the Medical School, University of Ioannina, Greece.

Author contributions: A. Lakatos: study concept and design. P. Kosta: analysis and interpretation of data. S. Konitsiotis: analysis and interpretation of data. A.K. Zikou: study concept and design. L.G. Astrakas: study concept and design, drafting/revising the manuscript for content. M.I. Argyropoulou: drafting/revising the manuscript for content.

Study funding: No targeted funding reported.

Disclosure: The authors report no disclosures relevant to the manuscript. Go to Neurology.org for full disclosures.

Correspondence to Dr. Argyropoulou: margyrop@cc.uoi.gr

1. Ménégon P, Sibon I, Pachai C, Orgogozo JM, Dousset V. Marchiafava-Bignami disease: diffusion-weighted MRI in corpus callosum and cortical lesions. Neurology 2005;65:475-477.

2. Gambini A, Falini A, Moiola L, Comi G, Scotti G. Marchiafava-Bignami disease: longitudinal MR imaging and MR spectroscopy study. AJNR Am J Neuroradiol 2003;24:249-253. 


\title{
Neurology
}

\author{
Marchiafava-Bignami disease: An acquired callosotomy \\ Andrea Lakatos, Paraskevi Kosta, Spyridon Konitsiotis, et al. \\ Neurology 2014;83;1219 \\ DOI 10.1212/WNL.0000000000000811
}

This information is current as of September 22, 2014

\section{Updated Information \&} Services

\section{References}

Subspecialty Collections

Permissions \& Licensing

Reprints including high resolution figures, can be found at: http://n.neurology.org/content/83/13/1219.full

This article cites 2 articles, 1 of which you can access for free at: http://n.neurology.org/content/83/13/1219.full\#ref-list-1

This article, along with others on similar topics, appears in the following collection(s):

\section{Alcohol}

http://n.neurology.org/cgi/collection/alcohol

DWI

http://n.neurology.org/cgi/collection/dwi

Generalized seizures

http://n.neurology.org/cgi/collection/generalized_seizures

MRI

http://n.neurology.org/cgi/collection/mri

Information about reproducing this article in parts (figures,tables) or in its entirety can be found online at:

http://www.neurology.org/about/about_the_journal\#permissions

Information about ordering reprints can be found online:

http://n.neurology.org/subscribers/advertise

Neurology ${ }^{\circledR}$ is the official journal of the American Academy of Neurology. Published continuously since 1951, it is now a weekly with 48 issues per year. Copyright @ 2014 American Academy of Neurology. All rights reserved. Print ISSN: 0028-3878. Online ISSN: 1526-632X.

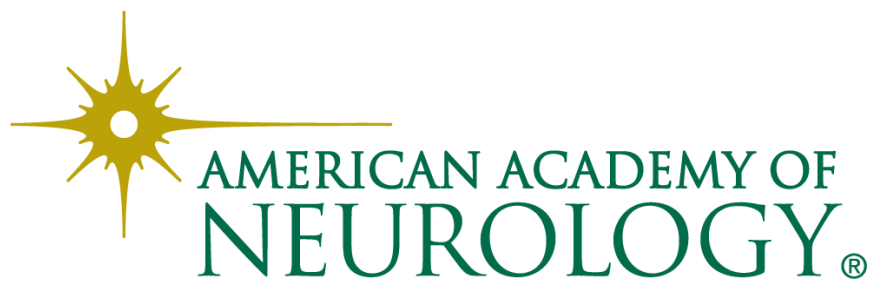

